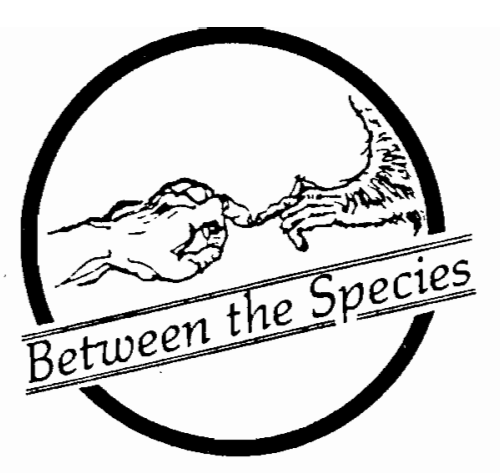

\title{
WHAT SHOULD A JEW DO?
}

Sidney Gendin

Eastern Michigan University

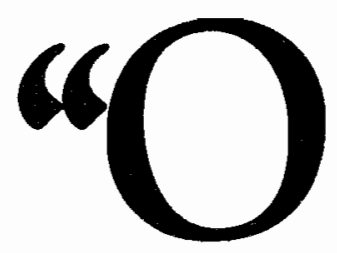

rthodox" is one of those words like "official" or "authority" meant to give weight to an otherwise lightweight concept. I heard an "authority" on the Civil War state that the "official" name for that war is "The War Between the States." I learned that he meant nothing more than that it was popularly socalled by many historians. The "authority" looked with righteous contempt upon "laymen" who didn't know any better.

We have a situation not unlike the above in the world of Judaic titles. In the 1800 s a group of rabbis hit upon the very unfortunate idea of calling their new movement "Reform Judaism." A responding group of rabbis then adopted the title "Orthodox." Ever since, it has been an uphill battle for the "Reform" Jews. "Reform" Jews eagerly desire respect and recognition from their rivals. This respect and recognition has never occurred and never will. The typical "Orthodox" Jew regards the

\section{$\underline{\text { Books Reviewed }}$}

Judaism and Vegetarianism, Richard $\mathrm{H}$. Schwartz. Exposition Press. (New York, 1982).

"Judaism and Animal Experimentation," J. David Bleich, in Animal Sacrifices: Religious Perspectives on the Use of Animals in Science, Tom Regan, editor. Temple University Press (Philadelphia, 1986). 
"Reform" Jew with contempt, as a particularly vile heretic not quite so fit to associate with as an admitted atheist. Even "humanistic" Jews, those proud of their heritage but who do not practice the religion, suppose that "real" Jews are "Orthodox" and that there is something of the sham about "Reformism." (I speak knowledgeably as one raised in a blended community of the "Orthodox" and the "humanistic," the son of immigrant parents who spoke Yiddish almost exclusively; I knew no non-Jews, apart from my teachers, until I finished college and entered graduate school.) Had those 19th century rabbis been shrewd enough to call their movement "Biblical Judaism," who can say for sure where the balance of prestige would lie today?

In the light of this background it is instructive to compare the reception Richard Schwartz's book, Judaism and Vegetarianism, is bound to receive within the Jewish community as a whole with the reception that will be accorded David Bleich's article, "Judaism and Animal Experimentation." Schwartz argues the case for vegetarianism for Jews. Bleich, despite the title of his article, defends a wide range of traditional exploitations of animals; experimentation gets almost insignificant coverage. Schwartz has a Ph.D. in civil engineering and is now a mathematics professor. He speaks to us from the "Reform" perspective. Bleich is a rabbi, a professor of Talmudic Studies at Yeshiva University, a former Visiting Scholar at the Oxford Center for post-graduate Hebrew Studies, and a member of the Board of Directors of the Union of Orthodox Jewish Congregations in America. In short, it is inevitable that Schwartz will have zero impact on the "Orthodox" and "Conservative" communities. ("Conservatism" is rather like a halfway house between "Orthodox" and "Reform.") On the other hand, Bleich will surely reinforce the views and practices of those communities, and it is likely he will exert influence on "Reform" and "humanistic" Jews alike. "Reform" Jews battle a sense of inferiority, a feeling they are not quite at the center of things, and are themselves inclined to think, grudgingly, that it is the "Orthodox" rabbi who is the "true" scholar. As for the "humanistic" Jew, s/he knows there are "Reform" rabbis who do not understand Hebrew and read only as much liturgical Hebrew as is necessary to conduct services. S/he may not change his/her practices after reading Bleich but s/he may well go away feeling that something s/he is doing is not strictly kosher.

To provide background for my discussion of Bleich and Schwartz, I want first to take a peek at some history of Jewish thought.

The Jewish Bible did not receive its final rabbinical ratification until sometime about 90 C.E., and that canonization includes only such books of the Old Testament as were produced prior to 250 B.C.E. Among those books, some are holier than others. In particular, the holiest are the first five books, called the Pentateuch by Christians and the Torah by Jews. In them one finds the details of Jewish law. The Torah is thought to be divine, written by Moses with his hand guided by God. But, as most of us know, the Torah is mainly a long narrative story, so that its rules and regulations tend to be concise and in need of interpretation. Accordingly, halakah (oral interpretation) is as old as the Torah itself. Sometime during the first century B.C.E., Torah "authorities" preached the doctrine that halakah was the "Oral" Torah, not just interpretation. Henceforth the first five books of the Old Testament were reduced to 
the "Written" Torah. The standard ploy of the early "sages" was that the "Written" Torah existed for the sake of the "Oral" Torah. In other words, the "Oral" Torah actually superceded the "Written" Bible in importance! Not surprisingly, almost immediately some people denied the divine status of the "Oral" Torah. Rabbi Akiva, the greatest "sage" of the time, used a tactic later to become common in the Christian hierarchy: he frightened these heretics by declaring that they would be excluded from the world-tocome. Akiva and other "authorities" announced that only those who studied the Torah full time were able to say whether the "Oral" Torah was divine. (About one thousand or so years later, Pope Innocent III forbade "laymen" from reading the Bible.)

Although the "sages" were confident that the tens of thousands of words comprising the "Oral" Torah had been faithfully passed down through the centuries without error, the practice of writing it down began during the era in which Akiva flourished. This written version of oral doctrine became known as the Mishnah and there were probably many versions of it. It was finally completed in the canonized version we know today by Judah-ha-Nasi somewhere around 200 C.E. Thereafter the Mishnah, not the "Written" Torah became the central concern of scholars.

For several centuries two principal centers of study each produced a Talmud - detailed commentaries on the Mishnah. In time the Babylonian center achieved, for reasons that needn't concern us, ascendancy over the Jerusalem center. Today, when Jews refer to "the" Talmud, it is that immense Babylonian work completed about 600 C.E. and running to two and a half million words that they have in mind. The Talmud, unlike the
Mishnah, is a scholarly work in which the Talmudic "sages" proved their points about Jewish law by citing passages in the Mishnah and often, too, in the "Written" Bible. Mishnah "sages" did not routinely quote biblical sources to prove a point. Indeed, what could have been the point of doing so? After all, the "Written" Torah was written for the sake of the "Oral" Torah. Despite the more humble approach of the Talmudists, in time the Talmud itself came to be regarded with the same reverence as the Mishnah. The 12th century "sage" Rashi declared that the study of the Talmud was more important than the study of the Torah. Even before Rashi the Talmud had become the chief object of study in the "post-Talmud rabbinic period" and it remains so to this day.

Although prior to the 19th century there had been Jewish sects (for example, Chassidism), the first serious challenge to rabbinic authority occurred in that century. In 1885 the leaders of the so-called "Reform" movement gathered in Pittsburgh and produced what has become known as the "Pittsburgh Platform." The following excerpt highlights a few interesting aspects of "Reform":

We hold that all such Mosaic and rabbinical laws as regulate diet ... originated in ages and under the influence of ideas entirely foreign to our present mental and spiritual state ... We consider ourselves no longer a nation but a religious community and therefore expect neither a return to Palestine nor the restoration of any of the laws concerning the Jewish state. [My emphasis.]

This passage is bold and daring, but the philosophy behind it need not have been expressed so provocatively. The Pittsburgh Platform could have emphasized the fact that the Torah teaches us moral principles, instead 
of rigid rules. ${ }^{1}$ Principles are not all-or-nothing rules like a traffic law that forbids any vehicle from travelling 30 miles per hour in a certain zone. With such rules either you are violating them or you are not. Instead, principles are factors to be weighed in decision-making. The Constitution, for example, is not a simple book of recipes laying down a code of conduct with precise instructions from which one never deviates. A principle outlawing "unreasonable searches" always puts a premium on intelligent deliberation: what is unreasonable at one time or place may be reasonable at another time or place.

The Pittsburgh Platform might have emphasized the fact that the Bible lays down principles of behavior that deserve to be abided by throughout all ages but, since intelligence is also never outdated, must be applied differentially in each epoch. It should have made clearer than it did that the circumstances of moral deliberation inevitably change and that much of what the Torah is concerned with were conditions peculiar to its time of composition. In fact, even the "Orthodox" make allowances for changing times. Here is an example. Traditionally, Jews tore a piece of their apparel at a funeral as a sign of respect for the dead. Today, "Orthodox" Jews pin a bit of ribbon to their clothes and then snip it with scissors. What do they take themselves to be doing? They ought to say that the symbolic meaning of the gesture remains intact. Really to tear one's clothes today is a sacrifice far and away greater than it was 2500 years ago. As we say today, "It's the gesture that counts." Instead, "Orthodox" Jews take themselves to be literally following a rule. In my view, this makes a mockery of the custom and does not respect it. It amounts to cheating. "Reform" Jews have pretty much abandoned the practice altogether and find other ways to obey the principle commanding that the dead be shown respect.

In 1984 a group of distinguished representatives of the world's major religions gathered in London for three days to discuss the use of animals in science from each of their particular religion's point of view. Among the invitees was Rabbi David Bleich. His presentation has now been published in the aforementioned book edited by Tom Regan. The article does not concern itself especially with animal experimentation. It ranges over all aspects of the treatment of animals, including the slaughter of animals for food. Bleich discusses each aspect with respect to $t z a^{\prime} a r b a^{\prime}$ alei hayyim - the pain of living creatures. Bleich's view is that Judaism is committed to reducing the pain of living creatures wherever this is feasible. The catch, obviously, is in determining when it is feasible. Bleich's method is to provide a scholarly survey of what various "sages" or "authorities" have had to say. He never writes that So and So argues for this and that but always says "In the opinion of this great sage," etc. In the course of his thirty page essay Bleich uses this expression, or some variant of it, at least twenty-two times that I noticed.

Bleich's summary view is that "In all likelihood, the rationale governing the strictures against tza'ar ba'alei hayyim is concern for the moral welfare of the human agent rather than concern for the physical welfare of the animals..." He "argues" for the reasonableness of this view by showing that it is shared by "many early authorities." Bleich doesn't mention it, but his view happens also to be the standard Kantian view. Kant's view has been subjected to extensive and rigorous criticism and found to be logically wanting. 2 The unargued for ground of Bleich's position is this: doing $\mathrm{x}$ may be perfectly decent considered by 
itself, but it may cause depraved attitudes in one who does it, and this depraved attitude will cause him to do things that are wrong. Now, of course this may sometimes be true, but in general there is no reason to think that practices unobjectionable in themselves will slide slipperily down a slope and result in evil character. Undoubtedly, none of the "sages" did the empirical research necessary to establish that hurting animals leads, say, to hurting children. Much more importantly, it is as plain as anything can be that hurting animals is bad in itself, and it is troubling to observe that there are "sages" unable to grasp that fact.

Among the celebrated "authorities" Bleich relies upon is Maimonides, who wrote that "The reason for the prohibition against eating a limb of a living animal is because this would make one acquire the habit of cruelty." Maimonides appears to think either that a cruel act is not bad unless it leads to the habit of cruelty or else that a cruel habit isn't bad unless it is practiced on humans. Why individual acts of cruelty are not bad unless habitual is a doctrine far too subtle for me. If Maimonides means the second possibility, i.e., that it is only cruelty habitually practiced on humans that is bad, then I leave the reader to decide if one can believe such a doctrine and be a "sage."

Bleich contentedly quotes Maimonides again when the latter writes, "Now since the necessity to have good food requires that animals be killed..." For thousands of years before Maimonides lived, and during his own age as well, there were vegetarians, a great many of whom lived as healthily as the omnivores and without any sense that they were undergoing any noble deprivation. Maimonides knew this as well as anyone did. Why then did he write the above? Well, why does anyone write such things? I personally know intelligent professional philosophers who also say that to have good food one must kill animals. They know, as well as any reader of this journal does, that there are life-long vegetarians who are now in their nineties. It is a matter of not taking animals seriously enough to bother with accuracy. People swear allegiance to the maxim "Thou shalt not kill" who regularly slaughter animals. It is not a matter of thinking that the maxim does not apply to animals. It is a matter of not thinking. Animals are simply not thought important enough to pause over the question, "Does the maxim apply to them?" I have no particular axe to grind about the question. Suffice it to say that not a single one of Bleich's "sages" or "authorities" confronts the question, "Must we eat animals to live well?," and consequently none has a single illuminating or even stupid thing to say about it. Bleich never pauses to raise the question, "Would it be wrong for a Jew to be a vegetarian?"

Bleich says that according to Jewish law meat may be consumed only if the animal has been slaughtered in conformity with a prescribed ritual. This is false. Most animals "Orthodox" Jews eat are not slaughtered in accordance with any ritual. Steve Sapontzis has estimated that humans kill many trillions of animals each year. All the farm animals slaughtered and all the wild animals trapped and hunted plus all the animals killed via vivisection together are but a small fraction of the number of animals people kill each year. "Official" estimates don't approach this estimate simply because the vast majority of animals we kill (fish and invertebrates) don't even deserve to be counted, much less deserve to be worried about. Bleich's remark reveals only his disdain for fish. He has no reason to think they cannot suffer. He simply doesn't think about them at all. 
Bleich holds that killing animals does not necessarily involve a form of tza'ar ba'alei hayyim and so isn't wrong per se. Do not suppose that this is because killing needn't be painful. Naturally, Bleich does not appeal to the Torah for this but, rather, trots out a long list of sayings by "sages" who agree with him; for example, Ri Migash proclaims that killing animals for human food is not $t z a^{\prime}$ ar ba'alei hayyim but killing them for dog food is. Bleich's final view is that pain may be inflicted on animals without violating the constraint on pain if the pain serves some "legitimate human purpose." What makes his view bizarre is his conception of what a legitimate purpose is. Quoting the Shulan Arukh (a codification of laws first printed in 1565, the following of which is regarded by the faithful as the "true" test of "orthodoxy"), Bleich says it is permissible to pluck the feathers of fowl before slaughter. Shulan Arukh concedes the practice is cruel but the overriding legitimate purpose is having quills for writing. Bleich invokes Talmudic "authorities" to maintain that at the funeral rites of a monarch it is permitted to sever the tendons of the horse on which the king rode as a way of bestowing honor on kings and princes. Bleich is not in the habit of raising an eyebrow and asking whether that is a legitimate purpose. Bleich approvingly quotes yet another "authority" who says a chicken's toe may be cut off to render it unfit for pagan sacrifice. He points out that the "majority of rabbinic authorities" cite financial gain as a legitimate benefit that may be pursued at the expense of $t z a^{\prime} a$ r ba'alei hayyim. Just about anything and everything ends up being permitted. All biomedical experiments, with anesthesia if appropriate (and by implication, without anesthesia if necessary) are fine with Bleich. Routine tox- icity testing, breaking the wings of birds so that they cannot fly away, and just about anything else you can think of turns out to be an exception to the proscription against inflicting pain on animals. Everything is proved by appeal to some rabbinic "authority" or other. Never once does Bleich grant himself the license to ask, "Granted that such and such practice is permitted, is it required? Can we live reasonably happy lives without sacrificing the animal? True, if we kill the cow we must slit its throat in a certain way, but would it be a terrible thing if we ate a tomato instead?" Bleich's article is a dutiful exposition of what greater men than he have thought and said. He knows they are greater, because they lived long ago. Not a single one of his "authorities" lived in the last two hundred years. I am reminded of the aphorism that a statesman is a politician who has been dead a long time.

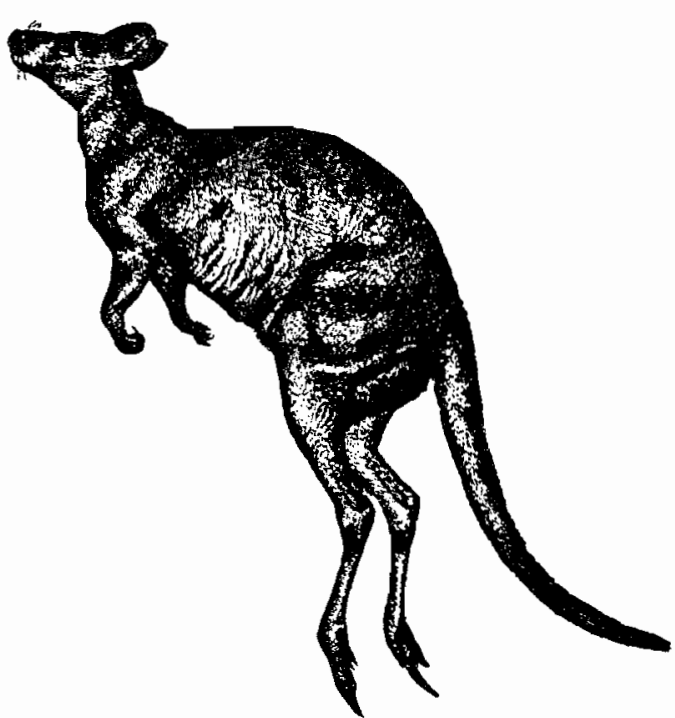

Jim Harter, Animals: 1419 Copyright-Free Illustrations. New York: Dover, 1979 
Schwartz's book is a refreshing contrast. His basic claim, made in the first two chapters, is that Jews ought to be vegetarians. The book contains much else besides. There are chapters on the health benefits of a vegetarian diet and on the advantages of vegetarianism for feeding the hungry of the world. Another chapter develops a connection between the peace movement and vegetarianism and there is one giving interesting biographies of famous Jewish vegetarians. Another chapter, donated by Shoshana Margolin, presents vegetarian recipes.

Schwartz understands that the world changes, and among those changes has been the introduction of intensive factory farming. Our economy is no longer agrarian, and because billions of people live today and the numbers will keep growing, there can be no retreat to the yesteryears of placid family farming. Inevitably, however they may be slaughtered, farm animals live miserable lives. Anyone who partakes of a flesh diet is bound to be violating the proscription against tza'ar ba'alei hayyim.

Schwartz quotes biblical passages to prove that compassion for animals is a direct moral requirement and does not derive from any worry that if we are cruel to them we will learn to be cruel to ourselves. All this is praiseworthy. Unfortunately, Schwartz tries to prove too much. He seems to think that vegetarianism is not only permitted by the Bible and required by contemporary realities; he thinks vegetarianism is strictly required by rigid rules of Judaism. His arguments and quotations are unconvincing. On the very first page of his book he quotes the passage in Genesis that reads, "Behold, I have given you every herb yielding seed which is upon the face of the earth, and every tree, in which is the fruit of a tree yielding seed - to you it shall be for food." Schwartz takes this to state a dietary law. It seems to be no such thing. Nothing in that passage implies or suggests that animals may not be eaten. Schwartz also thinks the passage, "And to every beast of the earth I have given every green herb for food" is a dietary law for animals. It is preposterous to think animals who eat animals are sinners. Later, according to Schwartz, God permitted people to eat animals, since they were a bunch of weak-willed wretches anyway. Later, again, God actually provided meat, in the form of quails, and when they ate the quails that put him in a fury. Now none of this seems attributable to a being worthy of being called "God." If we take our cue as to what to eat from God, let him act the part. Schwartz is much better when he is arguing, as Bleich never does, that it is a good thing not to eat animals, permitted or not. These arguments are developed mainly in the chapters on feeding the hungry and on the healthfulness of a vegetarian diet.

Sometimes Schwartz makes the mistake of appealing to the Talmud, "sages" and contemporary "authorities." He gets little mileage out of any of this. He makes the nearly calamitous mistake of citing a passage in the Talmud that reads, "Only one who studies Torah may eat meat, but one who does not study Torah is forbidden to eat meat." This is almost self-defeating. Schwartz wants to use the quotation to claim that very few Jews today are scholarly enough to justify their eating meat. But of course he should limit himself to arguments that say no one is entitled to eat meat, because that is what he actually believes. He should not appeal to "authorities" that have set themselves up as a class of privileged exceptions. Schwartz says that Talmud "authorities" strongly disapprove of hunting, but of what significance is that? The essence of "Reform" 
Judaism is its acceptance of progressive revelation according to which each Jew thinks for her/himself and makes her/his own discoveries as to what the Torah requires. Thus, the Talmudic "authorities" either had reasons for disapproving of hunting, or they didn't. If they had, it is the reasons that have authority, and we should be told what those reasons are so we may reflect on them. If they had no reasons, then their views are arbitrary and carry no weight. Near the end of his second chapter Schwartz makes the curious remark that Jewish slaughtering is the most humane form of slaughtering. I am unclear why he makes this "observation." Apart from the fact that the remark is counterproductive tactically, it has the minor vice of being patently false. The slaughter might be made more humane in many ways, e.g., administering an oral tranquilizer, followed by stunning, and only then followed by the kosher slaughtering ritual.

Schwartz's book is not the scholarly tract that Bleich's article is and, in any case, as I said at the outset, cannot hope to influence Jews in large numbers. But his book is readable, chock full of interesting stories and recipes. "Reform" Jews will enjoy it; "Orthodox" Jews won't go near it with a ten foot pole.

\section{$\underline{\text { Notes }}$}

${ }^{1}$ I owe the distinction between principles and rules to the philosopher-lawyer, Ronald Dworkin.

2 Although the critiques of Kant (and hence against Bleich) occur in very many places, the reader need only consult the clear and cogent discussion in Tom Regan's The Case for Animal Rights (Berkeley: University of California Press, 1983).

I am grateful to my friend and colleague, Scott Hoogerhyde, for many illuminating discussions on most of the points made in this paper.

Now 60 pages!
Not only the best writing on ethics and animals,
but fiction, poetry, and autobiography
by leading animal liberationists too!

